American Journal of Applied Sciences 6 (5): 922-928, 2009

ISSN 1546-9239

(C) 2009 Science Publications

\title{
Factor Influences Selection of Islamic Banking: A Study on Malaysian Customer Preferences
}

\author{
${ }^{1}$ Ahasanul Haque, ${ }^{2}$ Jamil Osman and ${ }^{1}$ Ahmad Zaki Hj Ismail \\ ${ }^{1}$ Department of Business Administration, \\ ${ }^{2}$ Faculty of Economics and Management Sciences, \\ International Islamic University Malaysia, P.O. Box 10, 50728 Kuala Lumpur, Malaysia
}

\begin{abstract}
The emergence of strong Islamic movements in last three decades has generated a renewed interest in Islamic economics, especially in Islamic interest free banking. Currently Islamic bank strategically offering high quality products and services to satisfy their customers due to the strong competition, customer expectation for high quality services and rapidly changes of technology. The purpose of this study is to investigate major factors that are reflecting to customers' perception and satisfaction on Islamic banking. This study hope to analyze and determine the perception, quality of services, availability of services, confidence in bank and social and religious perspective about Islamic banking system. A Logit model is employed to anticipate the effects of the explanatory variables. The analysis confirms the significant positive relationship of quality of services, availability of services, social and religious perspective and confidence in bank with customers' perception about Islamic bank. These factors are expected to have great role for influencing customer mind. In conclusion, customers can derive a better understanding of the activities that are undertaken by bank and how the way these activities are being dealt with.
\end{abstract}

Key words: Factors influences, product choice, customer preferences, Islamic banking

\section{INTRODUCTION}

Islamic banks have been operating like other traditional bank about four decades. They also mobilize deposits and produce loans based on Islamic Law (Shari'ah), which are different from the other conventional or commercial banks. Therefore, Islamic banking differs from conventional banking in several ways, such as the prohibition of transactions based on interest rate and the requirement that bank's operations be carried out according to certain procedures through the use of certain financial instruments ${ }^{[1]}$. However, the Islamic bank can also offer products and services which are similar to those offered by a conventional bank.

Generally, we can define the Islamic bank as a non-interest based financial institution which complies fully with Islamic Laws and has creative and progressive financial engineering to offer efficient and competitive banking, investment, trade finance, commercial and real estate financing services ${ }^{[1]}$. There are approximately 180 Islamic Banks and Financial Institutions operating in Asia, Africa, Europe and the USA with more than 8,000 branches with an estimated $\$ 170$ billion $^{[2]}$.
The popularity of the Islamic banking system is not limited to the Islamic banks only. Increasingly large international conventional banks are showing interest in the Islamic banking system as well ${ }^{[2]}$. The consequence of this is that Islamic banks operating in Islamic countries are faced with strong competition not only from Islamic banks but also from non-Islamic rivals ${ }^{[3]}$. When competition intensifies and when banks start to offer more or less similar products and services, it is the customer's satisfaction that can influence the performance of an Islamic bank and determines its competitiveness and success. Hence, it is of paramount importance to assess the degree of customer satisfaction towards Islamic banks operating in Islamic countries.

In this context, a number of questions can be raised. For example, in a country where the majority of the population are Muslims and where both Islamic as well as conventional banks operate, what are the main factors that motivate customers to deal with either an Islamic bank or a conventional bank or both?"; and to what extent customers are satisfied with their banks? ${ }^{[2]}$. In this study, an attempt is made to assess the degree of customer perception and awareness towards Islamic Bank by Malaysians. Since, Malaysia is viewed as one

Corresponding Author: Ahasanul Haque, Department of Business Administration, International Islamic University Malaysia, P.O. Box 10, 50728 Kuala Lumpur, Malaysia 
of the major players in the economic and political stability of the South East Asian region.

Islamic banking in Malaysia: The history of Islamic Banking in Malaysia can be traced to 1963 when Tabung Haji (the Pilgrims' Management and Fund Board) was established by the government. It is a specialized financial institution that provides a systematic mobilization of funds of Muslims to assist them to perform pilgrimage in Makkah as well as to encourage them to participate in investment opportunities and economic activities. In fact, due to its uniqueness, Tabung Haji is considered to be the first of its kind in the world.

Banking on the experience of Tabung Haji, the government of Malaysia had then introduced a coordinated and systematic process of implementing Islamic financial system. This process can be divided into three phases. The first phase is considered as the period of familiarization (1983-1992).This was the period when BIBM was established and the Islamic banking operations were started in accordance with Sharia'h principles. Listed on the main board of the Kuala Lumpur Stock Exchange (KLSE) on January 17th 1992, Bank Islam has developed itself as one of the most respectable financial institutions in the country.

The second phase (from 1993-2003) was aimed at creating a more conducive environment for competition among the banks. At the same time, it was to give banks ample time to try to capture a large market share. Lastly, while the intention was to create awareness among the public, especially Muslims, about the benefits of Islamic banking system, this was also the period when conventional banks were allowed to offer Islamic banking services by setting up "Islamic windows" or "Islamic banking scheme (IBS)" in 1993. The third phase that commenced from 2004 was the period of further financial liberation. During this period, the Central Bank paved the way for new foreign Islamic banks to operate in Malaysia by means of issuing licenses to them. Malaysia has emerged as the first country to implement a dual banking system, when Islamic banking system operates side-by-side with the conventional banking system. The Malaysian model has been recognized by many Islamic countries as the model of the future and many countries have shown interest in their respective countries.

Literature review: Customer satisfaction begins with clear, operational definitions from both the customer and the organization. Understanding the motivations, expectations and desires of both give a foundation in how to provide best service to the customer. It may even provide information on making improvements in the nature of business. This is the heart of research into customer satisfaction ${ }^{[4]}$. Clearly defining the key concepts and elements of satisfaction provides a template by which information can be gathered about what does and what does not work. This includes both the hard measures those that are more tangible and observable (i.e., number of complaints, average wait time, product returns, etc.) and the soft measures-those less tangible aspects (i.e., friendliness, helpfulness, politeness, etc. $)^{[5]}$. These definitions often start with the most vague and general one and end up with the highly specified and precise examples. The bottom line is that in order to know about customer satisfaction, one needs to know what to look for ${ }^{[6]}$. The organization needs to seek this information from both within and without. Research conducted on Islamic banking to examine customer satisfaction \& perception among Jordanian people $^{[2]}$. The analysis revealed a certain degree of satisfaction of many of the Islamic banks' facilities and products. The respondents expressed their dissatisfaction with some of the Islamic banks' services. Although the respondents indicated that they are aware of a number of specific Islamic financial products like Murabaha, Musharaka and Mudaraba, they show that they do not deal with them. This study indicates that it is important for Islamic banks to put cultural differences at the front when adopting SQ and suggests a new model to measure SQ called CARTER, which is based on 34 items. The study shows validity and significance of all CARTER items that have appeared in both weights and percentages of important items. Finally, the study suggests a scenario plan for KFH to adopt SQ and shows the importance of training to do so $^{[1]}$.

Moreover, explains that service quality is the customers' judgment about an entity's overall excellence or superiority ${ }^{[7]}$. It is a form of attitude and results from a comparison of expectations to perceptions of performance received. Define service quality as a measure of how well the service level delivered matches customer expectations ${ }^{[8]}$. Delivering quality service means conforming to customers' expectations on a consistent basis. The above definition makes it clear that service quality revolves around customers' expectations and perceptions of the services performed.

Customer satisfaction often depends on the quality of product or service offering. In the context of services, some describe customer satisfaction as an antecedent of service quality ${ }^{[9,10]}$. Service quality is thus related, though not equivalent, to satisfaction. For this 
reason, research on customer satisfaction is often closely associated with the measurement of quality ${ }^{[11]}$. Service quality has been described as a form of attitude that results from the comparison of expectations with performance ${ }^{[10,12]}$. A study argued that customers, while evaluating the quality of a service, compare the service they expect with perceptions of the services they actually receive ${ }^{[13]}$. It has been argued that the quality of service is not a unidimensional construct Rather, service quality incorporates various dimensions that relate to both core and augmented service offerings ${ }^{[14,8]}$. A research initially described five dimensions of service quality reliability, tangibles, responsiveness, assurance and empathy ${ }^{[15,16]}$. However the core or outcome aspects of the service and the relational or process aspect of the service have been identified as the two overriding dimensions to service quality ${ }^{[17,15]}$. Study conducted and argued that reliability was mainly concerned with the outcome of service whereas tangibles, responsiveness, assurance and empathy were concerned with the service delivery process ${ }^{[15]}$. The customers not only judge the accuracy and dependability (i.e., reliability) of the delivered service but they also judge the other dimensions as the service is being delivere ${ }^{[15]}$. Customer satisfaction can thus be based not only on the judgment of customers towards the reliability of the delivered service but also on customers' experiences with the service delivery process. This is the reason why in the services literature, we find strong emphasis on the importance of service quality perceptions and the relationship between customer satisfaction and service quality ${ }^{[10]}$. Research conducted and argues that satisfaction with a service encounter affects assessments of service quality and subsequent loyalty and switching behavior ${ }^{[9]}$. The recognition that there are positive (although not perfect) links between satisfactions in general, relationship satisfaction in particular and subsequent retention and repurchase highlight the importance of identifying and explaining the conditions under which satisfaction develops.

Research found that customer satisfaction mediates the effects of automated bank service quality on financial performance ${ }^{[18]}$. Customer satisfaction can thus be considered as the key construct to bank financial performance. However, this research found that Internet service quality had no significant relationship with customer satisfaction; improvement in the quality aspects of this dimension could enhance overall satisfaction and thus financial performance.

Results showed that service problems and the bank's service recovery ability have a major impact on customer satisfaction and intention to switch ${ }^{[17]}$. It is interesting to note that the bank's features and competitive interest rates were significant contributors to customer satisfaction. Researcher concludes that service quality in retail banking may comprise two basic dimensions-core and relational. In addition, items that reflect various features of the service offered are appropriate in the retail-banking sector of particular interest were the finding that three items did not load on any factor. This suggests that some aspects of service quality or the service offering that contribute to customer satisfaction are unidimensional.

A study found that religion did not play significant role to select an Islamic bank in Jordan but profit motivated criteria was an important factor to choose a bank opening new branches is also not a significant factor in Jordan ${ }^{[19]}$. However, other major findings are that peer group influence plays an important role in selecting Islamic banks as depository institution. The study explored that the demographic factors such as religion \& knowledge are playing a significant role to select a bank. Researcher found that customers do not have so much knowledge about the Islamic banking products such as Muderaba, Mushaaraka, Murabaha etc., but they buy these products for the reason of religion. Study also revealed that bank's name and reputation also strongly effect on selecting a bank. In this study, they explored that reputation and image factor are evidenced as one of the important criteria in the banking selection decision ${ }^{[20]}$.

\section{MATERIALS AND METHODS}

Conceptual framework: This study tries to identify the consumer perception about the Islamic banking and the relationship among the affective factors. Malaysia is a multicultural country but the percentage of Muslims is higher compare to other races (Chinese and Indian). Based on the discussion in literature review, it was identified that quality of services, confidence in bank, social and religious perspective and availability of services are the main factors affecting the customer satisfaction. Therefore, based on these factors theoretical framework of this study has been developed (Fig. 1).

Hypotheses of the study: Following hypothesis have been selected in the study based on the analytical interpretations in the previous section:

$\mathrm{H}_{1}$ : There is no significant difference between quality of services and customer perception

$\mathrm{H}_{2}$ : There is no significant difference between confidence in bank and customer perception 
Am. J. Applied Sci., 6 (5): 922-928, 2009

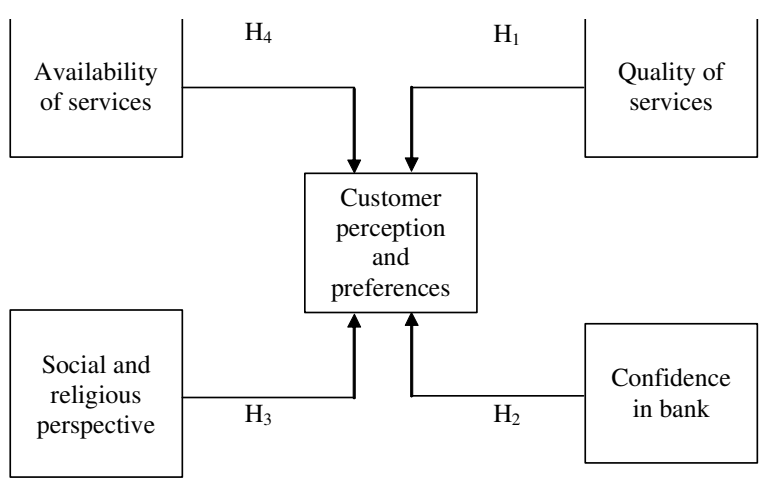

Fig. 1: Theoretical framework of the study

$\mathrm{H}_{3}$ : There is no significant difference between social and religious perspective and customer perception

$\mathrm{H}_{4}$ : There is no significant difference between availability of services and customer perception

Development of logit model: Logit model has been employed in this study for testing the hypotheses. Since, according to the special features of the Logit model are the mathematics of the model which guarantees that probabilities estimated from the Logit model will lie within the logical bounds of 0 and $1^{[21]}$. Moreover, in this model the probability of securing an 'A' does not increase linearly. In general, the logistic regression analysis is often used to investigate the relationship between these discrete responses and a set of explanatory variables. For developing a Logit model we define dependent variables as:

$$
\mathrm{CP}_{\mathrm{i}}=\mathrm{B}_{\mathrm{i} 11}+\mathrm{B}_{\mathrm{i} 12} \cdot \mathrm{QS}_{\mathrm{i}}+\mathrm{B}_{\mathrm{i} 13} \cdot \mathrm{CB}_{\mathrm{i}}+\mathrm{B}_{\mathrm{i} 14} \cdot \mathrm{SP}_{\mathrm{i}}+\mathrm{B}_{\mathrm{i} 15} \mathrm{AS}_{\mathrm{i}}+\mathrm{U}_{11}
$$

$\mathrm{CPi}=0$, if: Customer perception influences selection of Islamic banking

$\mathrm{CPi}=1$, if: Customer perception does not influences selection of Islamic banking

In this equation the dependent variable is a dummy variable which must be estimated in specific ways. From the above model we can say:

Probability (i) $=\mathrm{E}(\mathrm{CP}=1 \mid \mathrm{Xi})=\mathrm{B}_{\mathrm{i} 11}+\mathrm{B}_{\mathrm{i} 12} \cdot \mathrm{QS}_{\mathrm{i}}$ $+\mathrm{B}_{\mathrm{i} 13} \cdot \mathrm{CB}_{\mathrm{i}}+\mathrm{B}_{\mathrm{i} 14} \cdot \mathrm{SP}_{\mathrm{i}}+\mathrm{B}_{\mathrm{i} 15} \cdot \mathrm{AS}_{\mathrm{i}}$

$$
\begin{gathered}
\mathrm{Pi}=\mathrm{E}(\mathrm{CP}=1 / \mathrm{Xi})=\frac{1}{1+\mathrm{e}^{-\left(\mathrm{B}_{\mathrm{il1}}+\mathrm{B}_{\mathrm{it2}} \cdot \mathrm{QS}_{\mathrm{i}}+\mathrm{B}_{\mathrm{i} 13} \cdot \mathrm{CB}_{\mathrm{i}}+\mathrm{B}_{\mathrm{il1}} \cdot \mathrm{SP}_{\mathrm{i}}+\mathrm{B}_{115} \cdot \mathrm{AS}_{\mathrm{i}}\right.}} \\
\mathrm{Pi}=\mathrm{E}(\mathrm{CP}=1 / \mathrm{Xi})=1 / 1+\mathrm{e}^{-\mathrm{Zi}}
\end{gathered}
$$

Where:

$$
\mathrm{Zi}=\mathrm{B}_{\mathrm{i} 11}+\mathrm{B}_{\mathrm{i} 12} \cdot \mathrm{QS}_{\mathrm{i}}+\mathrm{B}_{\mathrm{i} 13} \cdot \mathrm{CB}_{\mathrm{i}}+\mathrm{B}_{\mathrm{i} 14} \cdot \mathrm{SP}_{\mathrm{i}}+\mathrm{B}_{\mathrm{i} 15} \cdot \mathrm{AS}_{\mathrm{i}}
$$

$$
\begin{gathered}
1-\mathrm{Pi}=\frac{1}{1+\mathrm{e}^{\mathrm{Zi}}} \\
\frac{\mathrm{Pi}}{1-\mathrm{Pi}}=\frac{1+\mathrm{e}^{\mathrm{Zi}}}{1+\mathrm{e}^{-\mathrm{Zi}}}=\mathrm{e}^{\mathrm{Zi}} \\
\mathrm{Li}=\operatorname{Ln}\left(\frac{\mathrm{Pi}}{1-\mathrm{Pi}}\right)=\mathrm{Zi} \\
\operatorname{Li}=\operatorname{Ln}\left(\frac{\mathrm{Pi}}{1-\mathrm{Pi}}\right)=\mathrm{B}_{\mathrm{i} 11}+\mathrm{B}_{\mathrm{i} 12} \cdot \mathrm{QS}_{\mathrm{i}}+\mathrm{B}_{\mathrm{i} 13} \cdot \mathrm{CB}_{\mathrm{i}}+\mathrm{B}_{\mathrm{i} 14} \cdot \mathrm{SP}_{\mathrm{i}}+\mathrm{B}_{\mathrm{i} 15} \cdot \mathrm{AS}_{\mathrm{i}}
\end{gathered}
$$

So, final Logit model is as follows:

$$
\mathrm{Li}=\mathrm{B}_{\mathrm{i} 11}+\mathrm{B}_{\mathrm{i} 12} \cdot \mathrm{QS}_{\mathrm{i}}+\mathrm{B}_{\mathrm{i13}} \cdot \mathrm{CB}_{\mathrm{i}}+\mathrm{B}_{\mathrm{i} 14} \cdot \mathrm{SP}_{\mathrm{i}}+\mathrm{B}_{\mathrm{i1} 5} \cdot \mathrm{AS}_{\mathrm{i}}
$$

Data collection: This study investigates factor influences of bank product selection in the context of Islamic banking. Therefore, Malaysian customers' of banking sector have been perceived to be the population of the study. The primary data had been used for this study and data were collected through distributing selfadministered questionnaire from the major part of the Peninsular Malaysia. A structured questionnaire was used for collecting the necessary information which are related to our research questions and related affective factors of customers' satisfaction on Islamic banking in Malaysia. The survey question consists of five specific sections and each section contains questions pertaining different parts or objectives of the study. Convenience sampling method has been used as a means of data collection procedure due to time and cost constraints and difficulty to access to the banking customers. The survey was conducted mainly via face-to-face interview. Some questionnaires also administrated through e-mail and postal services. A list of e-mail users was obtained from the TMNet which is currently registered with Telekom Malaysia (TM). Survey questionnaires were only e-mailed to them who are agreed to participate in the survey. This step was taken only to avoid the complaints from the Internet users and to increase the number of participants. Beside e-mail, the survey questionnaire was also posted to the Malaysian customers who are the member of the UseNet group. A total of 575 questionnaires were distributed and each of the responses received was screened properly for error, incomplete and missing responses. Efforts were also taken to contact the affected respondents through e-mail for clarification and correction, especially for missing and blanks responses. However, those responses that had more than $20 \%$ of the questions in the survey questionnaire left unanswered or incorrectly answered were deducted 
Am. J. Applied Sci., 6 (5): 922-928, 2009

from data analysis. After the screening process was carried out, 90 responses had been considered as unusable and the rest 485 responses were considered complete and valid for final analysis and hypothesis testing.

\section{RESULTS AND DISCUSSION}

Descriptive analysis has been employed to carry out the data analysis. Customers profile was one of the sections in the questionnaire in this study. Varies demographic factors were included there. A profile of respondents is shown in Table 1.

Table 1 showed that there is not too much difference between males and females in Malaysia terms of perception about Islamic banking. The males and females parentages of our respondent were 53.8 and 46.2 respectively. Since, all of the respondents are aware or heard about the Islamic banking. Data were collected from different age group. Large group of respondents were from 30-35 age group, followed by 25-30 age group. Moreover, major part of the respondent informed that they have completed graduation $(48.7 \%)$ and $22.2 \%$ respondent were completed post graduate degree. In addition, 23.9\% respondents were private sector employee, where as $23.5 \%$ respondents answered that they are government employee, followed by $19.4 \%$ are involved in teaching profession, $18.4 \%$ are students and $14.8 \%$ are businessman. In the case of the race $55.5 \%$ respondents were Malay, $23.1 \%$ Indian and rest $21.4 \%$ were Chinese. In the term of the monthly income, families with RM 2500-3500 income per month were the largest group among the respondents (35.7\%) then families with more than RM 4500 (8.7\%). Also $14.2 \%$ of respondents reported that they earn less than RM 1500 month $^{-1}$.

Frequency distribution of respondents showed that nearly $89.4 \%$ of respondents knew about Islamic banking. Bank provides information about the available facilities of Islamic banking services. Respondents were asked to report their familiarity with the Islamic banking services. The results showed that most of the respondents were not familiar with Islamic banking services. Indeed only $34.64 \%$ reported that they have Islamic bank account. Since, in order to investigate the customers' perception about Islamic banking it is important to explore where respondents held their accounts. Holding accounts in both an Islamic as well as a conventional bank enables customers to make useful comparison while evaluating quality of services. Details of respondents' account are reported in Table 2.
Table 1: Respondents demographic profile

\begin{tabular}{|c|c|c|c|c|}
\hline Descriptions & Frequency & Percentage & $\begin{array}{l}\text { Valid } \\
(\%)\end{array}$ & $\begin{array}{l}\text { Cumulative } \\
(\%)\end{array}$ \\
\hline \multicolumn{5}{|l|}{ Gender: } \\
\hline Male & 261 & 53.8 & 53.8 & 53.8 \\
\hline Female & 224 & 46.2 & 46.2 & 100.0 \\
\hline \multicolumn{5}{|l|}{ Age: } \\
\hline $15-20$ & 47 & 9.7 & 9.7 & 9.7 \\
\hline $21-25$ & 109 & 22.5 & 22.5 & 32.2 \\
\hline $25-30$ & 123 & 25.4 & 25.4 & 57.6 \\
\hline $30-35$ & 137 & 28.2 & 28.2 & 85.8 \\
\hline Above 35 & 69 & 14.2 & 14.2 & 100.0 \\
\hline \multicolumn{5}{|l|}{ Race: } \\
\hline Malay & 269 & 55.5 & 55.5 & 55.5 \\
\hline Chinese & 104 & 21.4 & 21.4 & 76.9 \\
\hline Indian & 112 & 23.1 & 23.1 & 100.0 \\
\hline \multicolumn{5}{|l|}{ Education: } \\
\hline STPM & 34 & 7.0 & 7.0 & 7.0 \\
\hline Diploma & 107 & 22.1 & 22.1 & 29.1 \\
\hline Graduate & 236 & 48.7 & 48.7 & 77.8 \\
\hline Post graduate & 108 & 22.2 & 22.2 & 100.0 \\
\hline \multicolumn{5}{|l|}{ Occupation: } \\
\hline Student & 89 & 18.4 & 18.4 & 18.4 \\
\hline Teacher & 94 & 19.4 & 19.4 & 37.8 \\
\hline Private sector employee & 116 & 23.9 & 23.9 & 61.7 \\
\hline Businessmen & 72 & 14.8 & 14.8 & 76.5 \\
\hline Govt. employee & 114 & 23.5 & 23.5 & 100.0 \\
\hline \multicolumn{5}{|l|}{ Monthly income: } \\
\hline Less than 1500 & 69 & 14.2 & 14.2 & 14.2 \\
\hline $1500-2500$ & 87 & 17.9 & 17.9 & 32.1 \\
\hline $2500-3500$ & 173 & 35.7 & 35.7 & 67.8 \\
\hline $3500-4500$ & 114 & 23.5 & 23.5 & 91.3 \\
\hline Above 4500 & 42 & 8.7 & 8.7 & 100.0 \\
\hline
\end{tabular}

Table 2: Types of bank(s) in which respondents hold their accounts

\begin{tabular}{llll}
\hline Value Label & Frequency & $(\%)$ & Cumulative \\
\hline Islamic Bank only & 168 & 34.64 & 34.64 \\
Conventional Bank only & 198 & 40.82 & 75.46 \\
Conventional and Islamic Banks & 119 & 24.54 & 100 \\
Total & 485 & 100 & \\
\hline
\end{tabular}

According to Table 2 more than $75 \%$ of respondents held accounts in Conventional bank and $24.54 \%$ respondents informed that they held accounts with an Islamic bank as well as a commercial bank.

In this study consumers' demographic characteristics entered as control variables which also influenced customers' perception about Islamic bank. Analysis of variance (ANOVA) has been used to investigate relationship between consumer perception toward Islamic bank and consumer demographic characteristics.

Consumer demographic characteristics had been divided into six factors including age, gender, education level, occupation, monthly income and race. Table 3 shows attitude mean based on the different categories and analyses of variance results for customers' demographics. According to the results with 95\% confidence, age does not have significant relationship with overall perception towards Islamic bank 
Am. J. Applied Sci., 6 (5): 922-928, 2009

Table 3: Analyses variance for consumer demographic characteristics

\begin{tabular}{lll}
\hline Consumer demographic items & F & Sig. \\
\hline (1) Age & 2.458 & 0.067 \\
(2) Gender & 8.012 & 0.014 \\
(3) Education & 0.735 & 0.613 \\
(4) Occupation & 0.257 & 0.877 \\
(5) Monthly Income & 3.321 & 0.071 \\
(6) Race & 1.768 & 0.013 \\
\hline
\end{tabular}

$(\mathrm{Sig}=0.067)$. Furthermore, there is no significant relationship between level of education and overall perception towards Islamic bank $(\mathrm{Sig}=0.613)$. Also with $95 \%$ confidence occupation $(\mathrm{Sig}=0.877)$ and monthly income $(\mathrm{Sig}=0.071)$ did not show significant relationship with overall perception towards Islamic bank. Despite these four factors, gender $(\mathrm{Sig}=0.014)$ and race $(\mathrm{Sig}=0.013)$ of respondents showed significant relationships with overall perception towards Islamic bank $(\mathrm{p} \leq 0.05)$.

Logistic model: In this study in order to investigate relationships among the factors related to the customer perception on Islamic banking, an econometric model has been adjusted. As the customer perception on Islamic banking is changing between zero and one, so the independent variable appropriately treated as a binary or two choices variable. The most obvious way to estimate this kind of models is Logistic model. In this study the following Logistic model is estimated:

$$
\begin{gathered}
\mathrm{P}\left(\mathrm{ES}_{\mathrm{j}}\right)=\frac{\exp \left\{\beta . X_{\mathrm{j}}\right\}}{1+\exp \left\{\beta . X_{\mathrm{j}}\right\}} \\
\beta=\left[\begin{array}{l}
\beta_{0} \\
\beta_{\text {Qualservs }} \\
\beta_{\text {ConBank }} \\
\beta_{\text {Soc Relgis }} \\
\beta_{\text {AvilServs }}
\end{array}\right] X_{j}=\left[\begin{array}{l}
1 \\
\text { QualServs } \\
\text { ConBank } \\
\text { SocRelgis } \\
\text { AvilServs }
\end{array}\right]
\end{gathered}
$$

Statistical software was used to estimate the logistic model. As the dependent variable of the model got values of 1 or 0 based on the respondent perception mode, all the questionnaires were not used for the estimation because some of the respondents are not aware of Islamic banking. Indeed, only those questionnaires, in which the respondent reported that he/she is familiar with the Islamic banking, were used for the estimation. From the total 485 questionnaires, only 168 respondents had Islamic bank account, therefore only 168 cases were used for estimating Logistic model (34.64\% of total data). According to the results of the analysis with $95 \%$ confidence all coefficient were significant. It means that customer perception about Islamic banking has significant relationship with four factors. The constant coefficient of the equation also was significant in same confidence level. The coefficients of the equation were estimated as below:

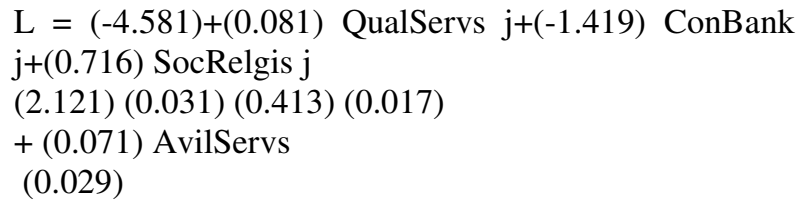

The results of the estimation showed that there is significant relationship between dependent variable of customer perception and independents variables. Based on the results of this part with $95 \%$ confidence, the four hypotheses were rejected. It means that customer perception about Islamic banking is being influenced significantly by quality of services, confidence in bank, social and religious perspective and availability of services. Three coefficients were positive values that mean positive relationship between customer perception and quality of services, social and religious perspective and availability of services. In other word, the positive values of coefficient revealed that positive perception towards Islamic banking. Furthermore, higher level of availability of services and social and religious perspective make the Islamic banking easier and comfortable. The negative value of the confidence in bank indicated that has less impact on customer perception.

\section{CONCLUSION}

The results of this study indicated customer perception can be mediated the effects of bank service quality on performance. Customer perception and satisfaction can be considered as the key contrast to bank for overall performance. In view of our findings, the provision of high standard of service quality may manage to increase customer satisfaction. While the study found that three coefficients are positive values which indicating significant relationship between customer perception and service quality, social and religious perspective and finally availability of services. It is means positive values of coefficient revealed that positive perception on Islamic banking. Moreover, availability of service and social, as well as religious perspective at higher level could make Islamic Banking easier and comfortable. On the other hand, negative values of confidence in Bank indicated comparatively less impact on customer perception for selecting bank products. 
Limitation and direction for further research: Limited time measurement for data collection and questionnaire survey are the key limitation for this study. The sample obtained by the survey instrument presents some challenges due to insufficient information. As Malaysian peoples have been chosen as population of the study, convenience sampling method may not be able to gather a comprehensive sample of population. Other sampling methods may give more accurate results, such as random sampling technique. Finally this study mainly investigates relationship between customers' perception towards Islamic bank and quality of service, confidence in bank, availability of services and social and religious perspective. However, due to scope limitations, this study could not mention relationship between the customers' perception and some other very important factors such as trust. Nevertheless, it can be hoped that such limitations would broadly suggest and encourage additional directions and guidelines for future studies.

\section{REFERENCES}

1. AbdulQawi, O. and O. Lynn, 2001. Adopting and measuring customer Service Quality (SQ) in Islamic Banks: A case study in Kuwait Finance House. Int. J. Islamic Financ. Servic., 3: 1-26.

2. Kamal, N., J. Ahmad and A.K. Khalid, 1999. Islamic Banking: A study of customer satisfaction and preferences in Jordan. Int. J. Bank Market., 17: $135-150$.

3. Naser, K. and L. Moutinho, 1997. Strategic marketing management: The case of Islamic Banks. Int. J. Bank Market., 15: 187-203.

4. Naylor, M. and S. Greco, 2002. Customer Chemistry: How to Keep the Customers You Want and Say "Good-bye" to the Ones You Don't, Chicago. McGraw-Hill.

5. Hayes, B., 1998. Measuring Customer Satisfaction, Milwaukee. ASQ Quality Press, WI.

6. Mitchell, J., 1999. Reaching across boarders. Market. News, 33: 19-21.

7. Zeithmal, V., 1987. Defining and retailing price, perceived quality and perceived value, Report No. 87-101. Marketing Science Institute. Cambridge. MA.

8. Lewis, R.C. and B.H. Booms, 1983. The Marketing Aspect of Service Quality. In: Emerging Perspectives on Services Marketing, Berry, L., G. Shostack and G. Upah (Eds.). American Marketing, Chicago, IL., pp: 99-107.
9. Bitner, M.J., 1990. Evaluating service encounters: The effects of physical surroundings and employee responses. J. Market., 54: 69-82.

10. Cronin, J.J. Jr. and S.A. Taylor, 1992. Measuring service quality: A re-examination and extension. J. Market., 56: 55-68.

11. East, R., 1997. Consumer Behaviour: Advances and Applications in Marketing. Prentice Hall, London.

12. Parasuraman, A., V. Zeithaml and L. Berry, 1985. A conceptual model of service quality and its implications for future research. J. Market., 49: 41-50.

13. Gronroos, C., 1982. Strategic Management and Marketing in the Service Sector, Swedish School of Economics and Business Administration, Helsingfors.

14. Gronroos, C., 1984. A service quality model and its marketing implications. Eur. J. Market., 18: 35-44.

15. Parasuraman, A., V. Zeithaml and L. Berry, 1991. Understanding customer expectations of service. Sloan Manage. Rev., 39: 39-48.

16. Parasuraman, A., V. Zeithaml and L. Berry, 1988. "SERVQUAL: A multi-item scale for measuring consumer perceptions of service quality. J. Retail., 64: $12-40$.

17. Levesque, T. and G.H.G. McDougall, 1996. Determinants of customer satisfaction in retail banking. Int. J. Bank Market., 14: 12-20.

18. Al-Hawari, M. and W. Tony 2006. The effect of automated service quality on australian banks' financial performance and the mediating role of customer satisfaction. Market. Intel. Plann., 24: 127-147.

19. Erol, C. and El.B. Radi, 1989. Attitude, behavior and patronage factors of bank customers towards Islamic Banks. Int. J. Bank Market., 7.

20. Yousuff, R. and K.N.Md. Azurah, 2006. Selection factors of Islamic Banking between Bank Islam Malaysia berhad and conventional banks amongst public servants in Kotakinabalu. Proceeding of the Annual Conference on Malaysian Finance Associations, May 8-9, pp: 315-329.

21. Gujarati, D.N., 1999. Essentials of Econometrics. 2nd Edn., McGraw-Hill, New York, USA. 